\title{
ANALISIS PENDAPATAN USAHATANI PADI SAWAH (Oryza sativa L) DI DESA KAUDITAN 1 KECAMATAN KAUDITAN KABUPATEN MINAHASA UTARA
}

\author{
Richard Christianto Katiandagho \\ Paulus A. Pangemanan \\ Tommy F. Lolowang
}

\begin{abstract}
This research aims to analyzed income of rice paddy farmers. This research conducted in Kauditan 1 village north Minahasa Regency from june to july 2018. The method used survey method by visiting rice paddy farming. Data collection method in this research using primary data. Primay data obtained from interview with rice paddy farmers using questionnaires, and secondary data from related agency statistic center bureau north Minahasa Regency. The sampling all rice paddy farmers, 5 respondent. Variable in this research is characteristic of farming: land area, land tenure status, seeds, fertilizers, medicine and characteristic of farmer: age, education level, family member, fixed cost, variable cost, total cost, price, production quantity. Data presented in the table form and analyzed descriptively. The result showed that average income of rice paddy farmers Rp.31,849,420 and average income based on land area Rp.18,780,342 with $R / C$ ratio more than 1,2.47.*iwths*
\end{abstract}

Keywords: income analysis, wet land paddy farming, Kauditan Village 1, Kauditan SubDistrict, North Minahasa Regency.

\begin{abstract}
ABSTRAK
Penelitian ini bertujuan untuk menganalisis berapa pendapatan petani padi sawah (Oryza sativa L). Penelitian ini dilakukan di Desa Kauditan 1, Kecamatan Kauditan, Kabupaten Minahasa Utara dan berlangsung selama bulan juni sampai bulan juli 2018. Metode penelitian yang dilakukan dalam penelitian ini adalah metode survei dengan cara mengunjungi petani padi sawah. Metode pengumpulan data dalam penelitian ini adalah dengan menggunakan data primer melalui kuesioner yang telah disiapkan yang diperoleh melalui wawancara langsung dengan petani serta data sekunder dari instansi terkait seperti Badan Pusat Statistik Kabupaten Minahasa Utara. Metode pengambilan sampel yaitu semua petani padi sawah dijadikan sebagai sampel sebanyak 5 responden. Konsep pengukuran variabel dalam penelitian ini adalah karakteristik usahatani meliputi luas lahan, status kepemilikan lahan, penggunaan benih, pupuk, obat-obatan, karakteritik petani meliputi umur, tingkat pendidikan, jumlah anggota keluarga, biaya tetap, biaya variabel, total biaya, harga, dan jumlah produksi. Analisis data yang digunakan adalah data yang diperoleh disajikan dalam bentuk tabel dan dianalisis secara deskriptif. Hasil penelitian menunjukan bahwa pendapatan rata-rata petani responden padi sawah di Desa Kauditan 1adalah Rp.31.849.420 dan pendapatan rata-rata berdasarkan luas lahan adalah Rp.18.780.342. Dengan nilai R/C lebih dari 1 yaitu 2,47.*lwths*.
\end{abstract}

Kata kunci: analisis pendapatan, usahatani padi sawah, Desa Kauditan 1, Kecamatan Kauditan, Kabupaten Minahasa Utara. 


\section{PENDAHULUAN}

\section{Latar Belakang}

Pertumbuhan pertanian di Indonesia memiliki peranan yang sangat penting dalam pembangunan ekonomi. Sejarah menunjukkan bahwa pembangunan pertanian merupakan prasyarat untuk adanya kemajuan dalam tahapan-tahapan pembangunan selanjutnya. Pertanian memiliki keterkaitan dengan berbagai aspek dalam perekonomian di Indonesia, maka pembangunan pertanian merupakan penentu utama dalam pertumbuhan ekonomi pedesaan, termasuk di dalamnya non-pertanian di pedesaan. Pembangunan pertanian menjadi bagian yang esensial bagi upaya-upaya pengurangan kemiskinan di pedesaan maupun di perkotaan. Indonesia sebagai negara agraris tidak boleh meninggalkan potensi pertaniannya, tetapi dengan merubah pola pikir primitive menjadi modern melalui pendidikan dan kebijakan pemerintah, maka posisi pertanian dapat memegang peranan penting lagi (Panggabean, 2010).

Peranan sektor pertanian sangat penting bagi pembangunan ekonomi masyarakat baik di pedesaan maupun di perkotaan. Salah satu peranan yang penting adalah menjaga ketersediaan pangan. Pangan merupakan kebutuhan dasar manusia. Untuk itu perlu adanya upaya-upaya untuk mencukupi ketersediaan pangan. Sektor pertanian juga dapat menjadi basis dalam mengembangkan kegiatan ekonomi pedesaan melalui pengemnbangan usaha berbasis pertanian atau agribisnis. Dengan memanfaatkan segala potensi dan sumber daya yang ada maka kegiatan usaha pertanian dapat membantu pertumbuhan ekonomi.

Menurut Pantjar Simatupang dalam bukunya. Agribisnis padi masih memegang peranan penting dalam perekonomian nasional. Pertama, beras masih merupakan makanan pokok penduduk Indonesia sehingga agribisnis padi berperan strategis dalam pemantapan ketahanan pangan, baik dalam penyediaan dan distribusi maupun akses terhadap beras guna menjamin kecukupan pangan penduduk. Kedua, agribisnis padi menciptakan lapangan kerja dan nilai tambah yang sangat besar karena hingga saat ini usahatani padi masih paling dominan dalam sektor pertanian. Ketiga, agribisnis padi sangat instrumental dalam upaya pengentasan kemiskinan.

Peran petani juga sangat mendukung dalam pengembangan ekonomi melalui usahatani yang dia jalankan. Adanya interaksi antara manusia dan sumber daya yang ada maka kegiatan usahatani dapat berjalan dengan baik. Dalam menjalankan kegiatan agribisnis padi sawah perlu dibutuhkan pengalaman yang baik dari petani sendiri dengan memperhatikan beberapa factor produksi sehingga kegiatan usahataninya berjalan dengan baik dan memperoleh keuntungan atau pendapatan yang diinginkan. Tujuan dari usahatani adalah untuk memperoleh pendapatan yang setinggitingginya bagi keluarga petani. Besarnya pendapatan ini dapat digunakan untuk menilai keberhasilan petani dalam mengelolah usahataninya, keberhasilan dalam berusahatani pada akhirnya akan ditentukan oleh biaya yang dikeluarkan dan penerimaan yang diperoleh dalam satu musim tanam. Manfaat utama dari pendapatan tersebut adalah untuk menjamin keberlanjutan usahataninya serta meningkatkan taraf hidup petani.

Di Kabupaten Minahasa Utara, tepatnya di Desa Kauditan 1, Kecamatan Kauditan terdapat kegiatan usahatani padi sawah. Dilihat dari penggunaannya, kurang lebih 80 persen dari Wilayah Kauditan digunakan sebagai lahan pertanian, yakni seluas 9.477 hektar. Dari total luas lahan pertanian tersebut, 76,14 persen atau 7.216 hektar lahan digunakan untuk kegiatan pertanian non sawah dan 23,86 persen atau 2.261 hektar digunakan untuk kegiatan pertanian sawah. Untuk komoditi tanaman padi-padian, padi yang dihasilkan di Kecamatan Kauditan adalah jenis padi sawah. Produksi padi sawah di Desa Kauditan adalah produksi yang 
terbesar dibanding dengan Kecamatan lainnya yang ada di Kabupaten Minahasa Utara (dapat dilihat pada Table 1). Dengan produksi yang besar maka kegiatan usahatani padi sawah di Desa Kauditan juga harus berimbang dengan pendapatan yang di terima oleh petani, maka perlu dilakukan penelitian untuk mengetahui besarnya pendapatan dan kelayakan usahatani padi sawah di Desa Kauditan 1 Kecamatan Kauditan, Kabupaten Minahasa Utara.

Tabel. 1 Jumlah Produksi Padi Sawah Di Kabupaten Minahasa Utara Tahun 2014-2015

\begin{tabular}{lcc}
\hline Kecamatan & $\begin{array}{c}\text { Luas Panen } \\
(\mathrm{Ha})\end{array}$ & $\begin{array}{c}\text { Produksi } \\
(\mathrm{Kg})\end{array}$ \\
\hline Kema & 620 & 3875 \\
Kauditan & 2063 & 15015 \\
Airmadidi & 335 & 2870 \\
Kalawat & 601 & 4007 \\
Dimembe & 1350 & 9806 \\
Talawaan & 1232 & 9441 \\
Wori & 58 & 348 \\
Likupang barat & - & - \\
Likupang timur & 273 & 1671 \\
Likupang selatan & 138 & 931 \\
\hline \multicolumn{1}{c}{2014} & 6395 & 40241 \\
\hline \multicolumn{1}{c}{2015} & 6670 & 47964 \\
\hline
\end{tabular}

Sumber: Dinas Pertanian, Peternakan dan Perkebunan Kabupaten Minahasa Utara.

\section{Rumusan Masalah}

Berdasarkan latar belakang yang telah diuraikan, maka yang menjadi masalah dalam penelitian ini adalah berapa besar pendapatan yang diterima oleh petani yang melakukan kegiatan usahatani padi sawah di Desa Kauditan 1 Kecamatan Kauditan Kabupaten Minahasa Utara.

\section{Tujuan Penelitian}

Penelitian ini bertujuan untuk menganalisis pendapatan dan kelayakan usahatani padi sawah di Desa Kauditan 1, Kecamatan Kauditan, Kabupaten Minahasa Utara.

\section{Manfaat Penelitian}

1. Sebagai tambahan ilmu mengenai analisis usahatani padi sawah.
2. Masukan bagi pemerintah Kabupaten Minahasa Utara.

3. Bisa menjadi referensi bagi penelitian selanjutnya tentang analisis usahatani padi sawah.

\section{METODE PENELITIAN}

\section{Waktu dan Tempat Penelitian}

Penelitian ini dilakukan selama 2 (dua) bulan dari bulan juni sampai dengan bulan juli 2018. Lokasi penelitan dilakukan di Desa Kauditan 1, Kecamatan Kauditan, Kabupaten Minahasa Utara. Di mana di desa ini Terdapat kegiatan berusahatani padi sawah.

\section{Metode Pengumpulan Data}

Metode Pengumpulan Data yang di lakukan adalah menggunakan metode survey. Pengambilan Data berupa data-data primer dan data-data sekunder. Data primer di peroleh dari hasil survey dan wawancara langsung dengan petani berdasarkan data pertanyaan yang telah di siapkandan dan data sekunder diperoleh dari instansi terkait yang berhubungan dengan penelitian ini.

\section{Metode Pengumpulan Sampel}

Metode pengambilan sampel yang di gunakan adalah metode purposive sampling atau secara sengaja. Anggota responden di pilih oleh peneliti. Jumlah responden yang di teliti yaitu sebesar 5 anggota responden dikarenakan sifatnya, tingkah lakunya dan karakteristiknya sama atau homogen.

\section{Konsep Pengukuran Variabel}

Adapun variabel-variabel yang di ukur dalam penelitian ini adalah:

1. Karakteristik usahatani padi sawah yang meliputi :

1) Luas lahan yaitu luas areal tanam padi, diukur dalam satuan hektar (ha).

2) Status Kepemilikan lahan ialah status lahan dibagi menjadi dua yaitu pemilik dan penyewa.

3) Penggunaan benih meliputi jenis benih dan jumlah benih. 
4) Penggunaan pupuk yang meliputi Jenis pupuk dan pupuk di ukur dalam satuan kilogram $(\mathrm{kg})$.

5) Penggunaan obat-obatan yang meliputi jenis obat dan jumlah benih, di ukur dalam satuan liter (L).

6) Karakteristik petani yang meliputi umur petani, tingkat pendidikan dan jumlah anggota keluarga.

2. Biaya tetap yang dikeluarkan oleh petani dalam satu musim tanam, meliputi pajak lahan, sewa lahan atau sewa gedung.

3. Biaya variabel yang di keluarkan oleh petani dalam satu musim tanam yang meliputi, benih, pupuk, pestisida, peralatan hingga biaya panen dan pasca panen.

4. Biaya total yang di keluarkan dalam satu musim tanam, dihitung dalam satuan rupiah (Rp).

5. Jumlah produksi yang dihasilkan dalam satu musim tanam, di ukur dalam satuan kilogram $(\mathrm{kg})$.

6. Harga padi gabah dan beras di tingkat petani dihitung dalam satuan rupiah ( $R p)$.

\section{Analisis Data}

Analisis data yang digunakan adalah analisis deskriptif dengan menggunakan table untuk mengetahui Besarnya pendapatan yang di peroleh petani dan menggunakan rumus :

Dimana:

$$
\pi=\mathrm{TR}-\mathrm{TC}
$$

$\pi=$ Pendapatan

$\mathrm{TR}=$ Total Penerimaan

$\mathrm{TC}=$ Total Biaya

\section{HASIL DAN PEMBAHASAN}

\section{Deskripsi Wilayah Penelitian}

\section{Letak Dan Luas Wilayah}

Desa Kauditan 1 adalah salah satu desa yang ada di Kecamatan Kauditan dari 12 desa yang ada. Desa Kauditan adalah desa dengan total produksi padi sawah terbesar di Kecamatan Kauditan. Jarak tempuh dari ibukota kabupaten adalah 13 (tiga Belas) kilometer.

Adapun batas-batas wilayah Desa Kauditan 1 adalah sebagai berikut:
1. Sebelah utara : Gunung Klabat

2. Sebelah selatan : Kecamatan Kema

3. Sebelah timur : Kota Bitung

4. Sebelah barat : Kecamatan Airmadidi

Desa Kauditan 1 memiliki luas wilayah $11,37 \mathrm{~km}^{2}$ dimana lahan pertanian seluas 9.477 hektar. Dan letak geografis desa kauditan 1 terletak antara $125^{\circ} 00^{\prime} 59.50^{\prime \prime}$ bujur timur (BT) dan $1^{\circ} 23$ '20.12" lintang utara (LU).

\section{Penduduk}

Jumlah kepala keluarga (KK) yang berdomsili di desa kauditan sebanyak 733 $\mathrm{KK}$, yang terdiri dari penduduk laki-laki berjumlah 1.529 jiwa dan penduduk perempuan 1.427 jiwa, jumlah keseluruhan 2.956 jiwa.

\section{Karakteristik Usahatani Berdasarkan \\ Luas Lahan}

Luas lahan sangat berpengaruh terhadap jumlah produksi usahatani padi sawah. Luas lahan juga menentukan jumlah pemakaian pupuk maupun obat-obatan yang akan digunakan oleh petani.

Tabel 2. Luas Lahan Petani Responden

\begin{tabular}{ccc}
\hline Resp & Luas Lahan (ha) & Presentase (\%) \\
\hline 1 & 3,00 & 35,29 \\
2 & 2,00 & 23,52 \\
3 & 1,00 & 11,76 \\
4 & 1,00 & 11,76 \\
5 & 1,50 & 17,67 \\
\hline Total & 8,50 & 100.00 \\
\hline
\end{tabular}

Dari Tabel 2 dapat dilihat bahwa luas lahan yang dimiliki oleh petani responden bervariasi dari 1 ha sampai dengan 3 ha.

\section{Status Kepemilikan Lahan}

Status kepemilikan lahan yang digarap oleh petani responden di desa kauditan 1 menentukan besar kecilnya penerimaan dan biaya serta pendapatan yang akan diterima oleh petani.

Tabel 3. Status Kepemilikan Lahan

\begin{tabular}{ccc}
\hline $\begin{array}{c}\text { Status } \\
\text { Kepemilikan }\end{array}$ & $\begin{array}{c}\text { Jumlah } \\
\text { Responden }\end{array}$ & Presentase (\%) \\
\hline Milik Sendiri & 1 & 20,00 \\
Sewa & 4 & 80,00 \\
\hline Total & 5 & 100.00 \\
\hline
\end{tabular}


Status kepemilikan lahan petani responden di desa kauditan 1 sebagian besar yaitu lahan sewa yang berjumlah 4 responden $(80,00 \%)$ dan 1 responden $(20,00 \%)$ yang lahannya adalah milik sendiri seperti pada Tabel 3.

\section{Karakteristik Petani Responden}

Karakteristik petani responden yang meliputi umur petani, tingkat pendidikan dan jumlah anggota keluarga juga berpengaruh terhadap usahatani dari segi kemampuan, sumber daya manusia dan hasil pendapatan petani dalam memenuhi tanggungan dalam keluarga.

\section{Umur Petani}

Umur petani akan mempengaruhi kemampuan fisik dalam bekerja. Dari segi kemampuan petani yang masih muda dan sehat akan berproduktifitas lebih besar dari petani yang sudah tua.

Tabel 4. Jumlah Petani Responden Menurut Kelompok Umur

\begin{tabular}{ccc}
\hline $\begin{array}{c}\text { Umur Petani } \\
\text { (Tahun) }\end{array}$ & $\begin{array}{c}\text { Jumlah Petani } \\
\text { (Orang) }\end{array}$ & $\begin{array}{c}\text { Presentase } \\
(\%)\end{array}$ \\
\hline $50-60$ & 3 & 60,00 \\
$61-70$ & 2 & 40,00 \\
\hline Jumlah & 5 & 100,00 \\
\hline
\end{tabular}

Pada Tabel 4 menunjukan bahwa petani responden yang berumur 50-60 tahun berjumlah 3 (tiga) orang dengan nilai presentase $(60,00 \%)$ sedangkan $61-70$ berjumlah 2 (dua) orang $(40,00 \%)$. Dari penjelasan tersebut menunjukan bahwa petani responden padi sawah di desa kauditan 1 sudah berumur di atas 50 tahun.

\section{Tingkat Pendidikan}

Pendidikan merupakan faktor yang sangat penting bagi petani terutama untuk peningkatan kualitas SDM. Adanya pendidikan dan ilmu yang memadai dapat meningkatkan kecakapan petani dalam melakukan kegiatan usahataninya. Petani akan lebih muda dalam mengadopsi dan menyerap petunjuk serta arahan dari penyuluh untuk diterapkan kedalam usahataninya.
Pendidikan juga berpengaruh terhadap kemampuan berpikir dan beradaptasi dengan lingkungannya serta penggunaan faktorfaktor produksi yang efisien sampai pada pemasaran produk usahataninya.

\begin{tabular}{ccc}
$\begin{array}{c}\text { Tabel 5. Jumlah } \\
\text { Tingkat Pendidikan }\end{array}$ & $\begin{array}{c}\text { Petani Responden } \\
\text { Penurut }\end{array}$ & Mendase \\
\hline Pendidikan & $\begin{array}{c}\text { Jumlah Petani } \\
\text { (Orang) }\end{array}$ & $\begin{array}{c}\text { Presentase } \\
(\%)\end{array}$ \\
& 3 & 60,00 \\
SD & 2 & 40,00 \\
SMA & 5 & 100,00 \\
\hline Jumlah &
\end{tabular}

Pada Tabel 5 didapati bahwa petani responden hanya berpendidikan sekolah dasar (SD) dan sekolah menengah atas (SMA). Petani yang jenjang pendidikan disekolah dasar berjumlah 3 (tiga) orang dan memiliki nilai presentase $(60,00 \%)$ dan yang berpendidikan dijenjang sekolah menengah atas berjumlah 2 (dua) orang dengan presentase $(40,00 \%)$.

\section{Jumlah Anggota Keluarga}

Tanggunan keluarga petani responden meliputi isteri dan anak yang tinggal bersamasama dengan petani sebagai kepala keluarga. Jumlah anggota keluarga biasanya berhubungan dengan tingkat kesejahteraan petani, semakin banyak anggota keluarga semakin besar pula pengeluaran untuk tanggungan dalam keluarga sehingga berpengaruh pada pendapatan petani.

Tabel 6. Jumlah Petani Responden Menurut Tingkat Pendidikan

\begin{tabular}{ccc}
\hline $\begin{array}{c}\text { Jumlah Anggota } \\
\text { Keluarga (Orang) }\end{array}$ & $\begin{array}{c}\text { Jumlah Petani } \\
\text { (Orang) }\end{array}$ & $\begin{array}{c}\text { Presentase } \\
(\%)\end{array}$ \\
\hline $1-2$ & 3 & 60,00 \\
$3-4$ & 2 & 40,00 \\
\hline Jumlah & 5 & 100,00 \\
\hline
\end{tabular}

Tabel 6 menunjukan jumlah anggota keluarga petani yang sedikit lebih mendominasi yaitu hanya 2 (dua) orang didalam keluarga sudah termasuk petani sebagai kepala keluarga dengan presentase $(60,00 \%)$ berjumlah 3 (tiga) orang sedangkan jumlah anggota keluarga berkategori 3-4 orang hanya 2 (dua) orang. Data di tabel ini 
menunjukan bahwa pengeluaran petani didalam tanggungan keluarga tidak terlalu besar dibandingkan dengan petani responden yang memiliki tanggungan lebih dari 2 (dua) orang.

\section{Pengolahan Dan Penanaman}

Pada kegiatan usahatani padi sawah pengolahan adalah tahap awal untuk mempersiapkan lahan yang akan ditanami. Pada tahap ini dimana dimulai dari pengolahan tanah hingga penyiapan lahan. Didesa kauditan 1 para petani responden sudah melakukan kegiatan usahatani secara bertahap jadi untuk mempersiapkan lahan tidak perlu membuka lahan baru untuk ditanami padi kecuali ada perluasan area tanam. Lahan yang akan ditanami sebelumnya sudah pernah digunakan untuk menanam padi dan sudah pernah panen.

Tabel 7. Penggunaan Beni Meliputi Jenis, Jumlah dan Harga

\begin{tabular}{clccr}
\hline Resp & Jenis Benih & $\begin{array}{c}\text { Pemakaian } \\
(\text { Sak })\end{array}$ & $\begin{array}{c}\text { Harga } \\
(\mathrm{Rp})\end{array}$ & $\begin{array}{c}\text { Total Biaya } \\
(\mathrm{Rp})\end{array}$ \\
\hline 1 & Membramu & 3 & 750.000 & 2.250 .000 \\
2 & Serayu & 2 & 750.000 & 1.500 .000 \\
3 & Superwin & 1 & 200.000 & 200.000 \\
4 & Pelawan & 2 & 250.000 & 500.000 \\
5 & Ciherang & 2 & 250.000 & 500.000 \\
\hline & Rata-rata & 2 & 440.000 & 990.000 \\
\hline
\end{tabular}

Dapat dilihat pada Tabel 7 bahwa penggunaan benih dan jumlah pemakaiannya tidak sama, harganya mulai dari kisaran Rp.200.000 sampai Rp.750.000. dan jenis benih tiap petani responden berbeda-beda, serta banyaknya benih tergantung luas lahan yang dimiliki petani responden.

\section{Pemupukan Dan Pemberantasan Hama}

Pemeliharaan tanaman adalah tahap yang sangat penting dimana kualitas tanaman akan mempengaruhi produksi dari usahatani tersebut. Tanaman padi yang baik dan tidak terserang hama dan penyakit adalah harapan dari semua petani, sehingga bisa mencapai hasil panen yang diinginkan. Pemberian pupuk dan obat-obatan pada tanaman padi harus sesuai dengan takaran dan dosis yang pas tergantung dari kebutuhan tanaman.

\begin{tabular}{|c|c|c|c|c|c|}
\hline Resp & Jenis Pupuk & $\begin{array}{c}\text { Pemakaian } \\
\text { (Sak) }\end{array}$ & Harga (Rp) & $\begin{array}{c}\text { Biaya } \\
(\mathrm{Rp})\end{array}$ & $\begin{array}{c}\text { Total } \\
\text { Biaya (Rp) }\end{array}$ \\
\hline \multirow[t]{2}{*}{1} & Urea & 20 & 100.000 & 2.000 .000 & 3.000 .000 \\
\hline & SP 36 & 8 & 125.000 & 1.000 .000 & \\
\hline \multirow[t]{2}{*}{2} & urea & 6 & 100.000 & 600.000 & 1.100 .000 \\
\hline & Ponska & 4 & 125.000 & 500.000 & \\
\hline \multirow[t]{2}{*}{3} & Urea & 6 & 100.000 & 600.000 & 975.000 \\
\hline & NPK & 3 & 125.000 & 375.000 & \\
\hline \multirow[t]{3}{*}{4} & Urea & 2 & 100.000 & 200.000 & 700.000 \\
\hline & Ponska & 2 & 125.000 & 250.000 & \\
\hline & SP3 & 2 & 125.000 & 250.000 & \\
\hline \multirow[t]{4}{*}{5} & Urea & 3 & 100.000 & 300.000 & 1.080 .000 \\
\hline & $\mathrm{KCL}$ & 3 & 125.000 & 375.000 & \\
\hline & Ponska & 3 & 135.000 & 405.000 & \\
\hline & Rata-rata & 5.17 & 115.417 & 571.250 & 1.371 .000 \\
\hline
\end{tabular}

Dari data yang didapat pada Tabel 8 bahwa penggunaan pupuk tiap petani responden bervariasi. Pada responden 1 pengguanan pupuk lebih banyak dari responden lainnya dikarenakan luasan ha yang lebih besar dan biaya dalam pembelian pupuk responden 1 mencapai Rp.3.000.000 berbeda dengan responden 4 yang jumlahnya hanya Rp.700.000.

Tabel 9. Penggunaan Obat-obatan Meliputi Jenis, Jumlah Dan Harga

\begin{tabular}{cccrr}
\hline Resp & $\begin{array}{c}\text { Jenis Jenis } \\
\text { Obat }\end{array}$ & $\begin{array}{c}\text { Pemakaian } \\
\text { (Botol/Sachet) }\end{array}$ & $\begin{array}{c}\text { Harga } \\
(\mathrm{Rp})\end{array}$ & $\begin{array}{c}\text { Total Biaya } \\
(\mathrm{Rp})\end{array}$ \\
\hline 1 & 2 & 24 & 85.000 & 2.040 .000 \\
2 & 3 & 18 & 240.000 & 4.320 .000 \\
3 & 2 & 8 & 80.000 & 640.000 \\
4 & 2 & 4 & 80.000 & 320.000 \\
5 & 4 & 20 & 200.000 & 4.000 .000 \\
\hline Rata-rata & 2.6 & 14.8 & 137.000 & 2.264 .000 \\
\hline
\end{tabular}

Dapat dilihat pada Tabel 9 penggunaan obat-obatan juga bervariasi responden 2 biayanya lebih besar dari responden yang lainnya dikarenakan jumlah obat dan jenis serta harga obat yang dia pakai berbeda. Waktu penyemprotan dilakukan 2 sampai 3 kali penyemprotan tergantung dari luas lahan.

\section{Biaya Tenaga Kerja}

Biaya tenaga kerja petani responden dalam proses produksi padi sawah dalam satu kali musim tanam mulai dari pengolahan, penanaman, pemeliharaan dan sampai pada proses panen yaitu meliputi dari jumlah tenaga kerja yang dipakai. Tenaga kerja yang dipakai ada yang berasal dari dalam keluarga yaitu petani yang dibantu anggota keluarganya dan ada yang berasal dari luar keluarga yaitu petani juga menggunakan orang kerja dalam mengolah sawahnya. Upah tenaga kerja yang berasal dari luar keluarga untuk semua petani responden nilai upahnya sama yaitu dibayar dengan nilai 
Rp.100.000 perhari, jika pengolahan sawah sampai panen, total upah yang dibayar dikalikan dengan hari orang kerja (HOK).

Tabel 10. Biaya Tenaga Kerja Pengolahan

\begin{tabular}{cccccc}
\hline Resp & \multicolumn{2}{c}{ Jumlah TK } & $\begin{array}{c}\text { Biaya/Hari } \\
(\mathrm{Rp})\end{array}$ & HOK & $\begin{array}{c}\text { Biaya } \\
(\mathrm{Rp})\end{array}$ \\
\cline { 2 - 4 } & DK & LK & 100.000 & 3 hari & 900.000 \\
1 & 2 & 3 & 100.000 & 3 hari & 600.000 \\
2 & 2 & 2 & 100.000 & 4 hari & 800.000 \\
3 & 3 & 2 & 100.000 & 2 hari & 800.000 \\
4 & 4 & 4 & 100.000 & 3 hari & 900.000 \\
5 & 2 & 3 & & & \\
\hline
\end{tabular}

Tabel 11. Biaya Tenaga Kerja Penanaman

\begin{tabular}{cccccr}
\hline Resp & \multicolumn{2}{c}{ Jumlah TK } & $\begin{array}{c}\text { Biaya/Hari } \\
(\mathrm{Rp})\end{array}$ & HOK & \multicolumn{1}{c}{$\begin{array}{c}\text { Biaya } \\
(\mathrm{Rp})\end{array}$} \\
\cline { 2 - 4 } & DK & LK & 100.000 & 3 hari & 900.000 \\
1 & 2 & 3 & 100.000 & 3 hari & 900.000 \\
2 & 2 & 3 & 100.000 & 4 hari & 1.200 .000 \\
3 & 3 & 3 & 100.000 & 3 hari & 1.500 .000 \\
4 & 4 & 5 & 100.000 & 3 hari & 1.500 .000 \\
5 & 2 & 5 & & & \\
\hline
\end{tabular}

Tabel 12. Biaya Tenaga Kerja Pemeliharaan

\begin{tabular}{cccccc}
\hline Resp & \multicolumn{2}{c}{ Jumlah TK } & $\begin{array}{c}\text { Biaya/Hari } \\
\text { (Rp) }\end{array}$ & HOK & $\begin{array}{c}\text { Biaya } \\
(\mathrm{Rp})\end{array}$ \\
\cline { 2 - 5 } & DK & LK & & 3 hari & 300.000 \\
1 & 2 & 1 & 100.000 & 3 hari & 600.000 \\
2 & 2 & 2 & 100.000 & 2 hari & 400.000 \\
3 & 3 & 2 & 100.000 & 3 hari & 600.000 \\
4 & 4 & 2 & 100.000 & 4 hari & 800.000 \\
5 & 2 & 2 & 100.000 & & \\
\hline
\end{tabular}

Tabel 13. Biaya Tenaga Kerja Panen

\begin{tabular}{cccccr}
\hline Resp & \multicolumn{2}{c}{ Jumlah TK } & $\begin{array}{c}\text { Biaya/Hari } \\
(\text { Rp })\end{array}$ & HOK & \multicolumn{1}{c}{$\begin{array}{c}\text { Biaya } \\
(\text { Rp })\end{array}$} \\
\cline { 2 - 3 } & DK & LK & & 900.000 \\
2 & 2 & 3 & 100.000 & 3 hari & 900.000 \\
3 & 2 & 3 & 100.000 & 3 hari & 900.000 \\
4 & 3 & 7 & 100.000 & 5 hari & 3.500 .000 \\
5 & 4 & 3 & 100.000 & 4 hari & 1.200 .000 \\
\hline
\end{tabular}

Penjelasan data dari Tabel 10 sampai Tabel 13 bahwa penggunaan tenaga kerja yang berasal dari dalam keluarga maupun yang berasal dari luar keluarga tidak sama dari tiap petani responden, dikarenakan jumlah anggota keluarga, penggunaan orang kerja dan HOK yang berbeda sehingga biaya yang dikeluarkan petani responden bervariasi.

\section{Biaya Lahan Dan Peralatan}

Biaya lahan terbagi dari pajak lahan dan sewa lahan yang dikeluarkan oleh petani responden. Penggunaan alat-alat pertanian berupa mesin traktor, mesin perontok dan mesin penggiling dari semua petani responden statusnya masih menyewa dikarenakan tidak memiliki alat-alat tersebut.
Tabel 14. Biaya Pajak Lahan Dan Sewa Lahan

\begin{tabular}{ccc}
\hline Resp & $\begin{array}{c}\text { Pajak Lahan } \\
(\mathrm{Rp})\end{array}$ & $\begin{array}{c}\text { Sewa Lahan } \\
(\mathrm{Rp})\end{array}$ \\
\hline 1 & - & 4.200 .000 \\
2 & - & 6.600 .000 \\
3 & - & 3.600 .000 \\
4 & 50.000 & - \\
5 & - & 1.800 .000 \\
\hline Rata-rata & 50.000 & 4.050 .000 \\
\hline
\end{tabular}

Tabel 14 menunjukan bahwa hanya responden 4 yang membayar pajak dikarenakan lahan yang digarapnya adalah milik sendiri berbeda dengan responden $1,2,3$, dan 5 yang status lahannya menyewa dari orang lain. Harga sewa dari responden tersebut berbeda sesuai dengan harga yang diberikan oleh pemilik lahan.harga sewa lahan yang diberikan oleh pemilik lahan adalah dengan sistem bagi hasil, jadi dari bagi hasil didapat nominal rupiah yang diberikan kepada pemilik lahan.

Tabel 15. Biaya Penyewaan Alat Pertanian

\begin{tabular}{ccccc}
\hline Resp & Traktor & Perontok & Penggiling & Biaya (Rp) \\
\hline 1. & 3.000 .000 & 750.000 & 9.000 .000 & 12.750 .000 \\
2. & 3.500 .000 & 750.000 & 6.600 .000 & 10.850 .000 \\
3. & 3.000 .000 & 750.000 & 4.800 .000 & 8.550 .000 \\
4. & 1.800 .000 & 750.000 & 2.700 .000 & 5.250 .000 \\
5. & 2.500 .000 & 750.000 & 2.400 .000 & 5.650 .000 \\
\hline Rata-rata & 2.760 .000 & 750.000 & 5.100 .000 & 8.610 .000 \\
\hline
\end{tabular}

Sewa alat dari tiap responden hanya penyewaan traktor yang berbeda selanjutnya sewa mesin perontok harga sewahnya sama. Penyewaan mesin penggiling sistemnya dari total produksi dan penerimaan petani dikurangi $10 \%$, dan hasil dari $10 \%$ itu yang dibayarkan kepada pemilik mesin penggiling.

Tabel 16. Biaya Penyusutan Alat

\begin{tabular}{cccc}
\hline Resp & Parang & Cangkul & Tangki. S \\
\hline 1 & 16.667 & 4.444 & 15.000 \\
2 & 11.111 & 3.333 & 19.000 \\
3 & 18.889 & 4.444 & 11.667 \\
4 & 16.111 & 3.333 & 10.667 \\
5 & 16.667 & 4.444 & 15.000 \\
\hline Rata-rata & 15.889 & 4.000 & 14.267 \\
\hline
\end{tabular}

Penyusutan atau depresiasi adalah biaya pengurangan nilai yang disebabkan oleh karena pemakaian alat selama proses kegiatan usahatani. Biaya penyusutan dihitung dari masa pakai alat yang digunakan dalam proses sekali musim tanam yaitu 4 (empat) bulan di bahagi 
umur dari alat yang dipakai dan dikalikan dengan harga beli dari alat tersebut.

Perhitungan biaya penyusutan pada tabel 16 menggunakan rumus sebagai berikut:

Masa pakai alat

Umur alat $X$ Harga Barang

\section{Biaya Usahatani}

Total biaya usahatani adalah total dari keseluruhan biaya yang dikeluarkan oleh petani responden selama proses produksi padi sawah baik biaya secara keseluruhan maupun biaya berdasarkan luas lahan.

\begin{tabular}{|c|c|c|c|c|c|c|}
\hline Resp & Benih & Pupuk & Obat-obatan & $\begin{array}{c}\text { Tenaga } \\
\text { Kerja }\end{array}$ & $\begin{array}{l}\text { Lahan \& } \\
\text { Peralatan }\end{array}$ & $\begin{array}{c}\text { Total Biaya } \\
\text { (TC) }\end{array}$ \\
\hline 1 & 2.250 .000 & 3.000 .000 & 2.040 .000 & 1.600 .000 & 16.977 .050 & 27.267 .050 \\
\hline 2 & 1.500 .000 & 1.100 .000 & 4.320 .000 & 1.400 .000 & 17.475 .050 & 27.395 .050 \\
\hline 3 & 200.000 & 975.000 & 640.000 & 5.900 .000 & 12.176 .050 & 19.891 .050 \\
\hline 4 & 500.000 & 700.000 & 320.000 & 4.100 .000 & 5.322 .500 & 10.942 .500 \\
\hline 5 & 500.000 & 1.080 .000 & 4.000 .000 & 5.200 .000 & 7.477 .250 & 18.257 .250 \\
\hline Rata-rata & 990.000 & 1.371 .000 & 2.264 .000 & 3.640 .000 & 11.885 .580 & 20.750 .580 \\
\hline
\end{tabular}

Tabel 18. Biaya Usahatani Menurut Luas Lahan

\begin{tabular}{ccc}
\hline Resp & Luas Lahan (Ha) & Total Biaya (Rp) \\
\hline 1 & 3,00 & 9.089 .017 \\
2 & 2,00 & 13.697 .525 \\
3 & 1,00 & 19.891 .050 \\
4 & 1,00 & 10.942 .500 \\
5 & 1,50 & 12.171 .500 \\
\hline Rata-rata & 1,70 & 13.018 .318 \\
\hline
\end{tabular}

Hasil dari Tabel 17 dan 18 mendapatkan rata-rata untuk total biaya keseluruhan adalah Rp.20.750.580 sedangkan rata-rata untuk biaya usahatani berdasarkan luas lahan adalah Rp.13.018.318.

\section{Penerimaan Usahatani}

Penerimaan adalah hasil yang dicapai oleh petani dengan harapan mendapatkan hasil yang baik. Penerimaan petani responden bervariasi tergantung dari luasan lahan yang dimiliki. Penerimaan secara keseluruhan dan penerimaan berdasarkan luas lahan yang diterima petani responden di Desa Kauditan 1 dengan penjelasan pada tabel berikut.
Tabel 19. Penerimaan Usahatani

\begin{tabular}{cccc}
\hline Resp & $\begin{array}{c}\text { Jumlah Produksi } \\
\text { Beras }(\mathrm{Kg})\end{array}$ & $\begin{array}{c}\text { Harga Beras } \\
(\mathrm{Rp})\end{array}$ & $\begin{array}{c}\text { Total } \\
\text { Penerimaan } \\
(\mathrm{TR})\end{array}$ \\
\hline 1 & 9.000 & 10.000 & 90.000 .000 \\
2 & 6.600 & 10.000 & 66.000 .000 \\
3 & 4.800 & 10.000 & 48.000 .000 \\
4 & 2.700 & 10.000 & 27.000 .000 \\
5 & 3.200 & 10.000 & 32.000 .000 \\
\hline Rata-rata & 5.260 & 10.000 & 52.600 .000 \\
\hline
\end{tabular}

Tabel 20. Penerimaan Usahatani Menurut Luas Lahan

\begin{tabular}{cccc}
\hline Resp & $\begin{array}{c}\text { Luas Lahan } \\
(\mathrm{Ha})\end{array}$ & $\begin{array}{c}\text { Jumlah Produksi } \\
\text { Beras }(\mathrm{Kg})\end{array}$ & $\begin{array}{c}\text { Total } \\
\text { Penerimaan } \\
(\mathrm{TR})\end{array}$ \\
\hline 1 & 3,00 & 3.000 & 30.000 .000 \\
2 & 2,00 & 3.300 & 33.000 .000 \\
3 & 1,00 & 4.800 & 48.000 .000 \\
4 & 1,00 & 2.700 & 27.000 .000 \\
5 & 1,50 & 2.133 & 21.300 .000 \\
\hline Rata-rata & 1,70 & 3.187 & 31.860 .000 \\
\hline
\end{tabular}

Tabel 20 menunjukkan bahwa penerimaan petani berbeda, jumlah produksi yang besar akan mendapatkan keuntungan rupiah yang besar pula tergantung dari luasan lahan masing-masing petani responden. Luas lahan yang lebih besar maka jumlah produksi akan ikut naik dan mendapatkan keuntungan yang lebih. Harga jual merupakan salah satu faktor yang penting sehingga menentukan besarnya penerimaan dari usahatani padi sawah.

\section{Pendapatan Usahatani}

Pendapatan usahatani adalah merupakan selisih antara total penerimaan dengan total biaya. Berusahatani adalah suatu aktifitas untuk memperoleh hasil pada usahataninya yang pada akhirnya akan dinilai dari biaya yang dikeluarkan dan penerimaan yang diperoleh.

Pendapatan dalam pengertiannya dapat dikatakan sebagai selisih antara penerimaan dengan biaya yang dihitung dalam jangka waktu tertentu. Dalam penelitian ini pendapatan yang dihitung adalah selama satu kali musim tanam. Pendapatan usahatani padi sawah didesa kauditan 1 dapat dilihat pada tabel berikut.

Tabel 21. Pendapatan Usahatani

\begin{tabular}{cccc}
\hline Resp & $\begin{array}{c}\text { Total Penerimaan } \\
(\mathrm{TR})\end{array}$ & $\begin{array}{c}\text { Total Biaya } \\
(\mathrm{TC})\end{array}$ & $\begin{array}{c}\text { Total } \\
\text { Pendapatan } \\
(\pi)\end{array}$ \\
\hline 1 & 90.000 .000 & 27.267 .050 & 62.732 .950 \\
2 & 66.000 .000 & 27.395 .050 & 38.604 .950 \\
3 & 48.000 .000 & 19.891 .050 & 28.108 .950 \\
4 & 27.000 .000 & 10.942 .500 & 16.057 .500 \\
5 & 32.000 .000 & 18.257 .250 & 13.742 .750 \\
\hline Rata-rata & 52.600 .000 & 20.750 .580 & 31.849 .420 \\
\hline
\end{tabular}


Tabel 22. Pendapatan Usahatani Menurut Luas Lahan

\begin{tabular}{|c|c|c|c|c|}
\hline Resp & $\begin{array}{c}\text { Luas } \\
\text { Lahan } \\
\text { (Ha) }\end{array}$ & $\begin{array}{c}\text { Total } \\
\text { Penerimaan } \\
\text { (Rp) }\end{array}$ & $\begin{array}{c}\text { Total } \\
\text { Biaya (Rp) }\end{array}$ & $\begin{array}{c}\text { Total } \\
\text { Pendapatan } \\
(\mathrm{Rp})\end{array}$ \\
\hline 1 & 3,00 & 30.000 .000 & 9.089 .017 & 20.910 .983 \\
\hline 2 & 2,00 & 33.000 .000 & 13.697 .525 & 19.302 .475 \\
\hline 3 & 1,00 & 48.000 .000 & 19.891 .050 & 28.108 .950 \\
\hline 4 & 1,00 & 27.000 .000 & 10.942 .500 & 16.057 .500 \\
\hline 5 & 1,50 & 16.000 .000 & 12.171 .500 & 9.161 .800 \\
\hline Rata-rata & 1,70 & 30.800 .000 & 13.018 .318 & 18.708 .342 \\
\hline
\end{tabular}

Berdasarkan Tabel 21 dan Tabel 22 dapat dilihat bahwa total pendapatan responden 1 memiliki pendapatan yang lebih tinggi dibanding dengan responden lainnya yaitu Rp.62.732.950 karena luas lahan dan produksinya lebih besar dari pada 4 responden yang lain. Responden 2 memiliki pendapatan Rp.38.604.950. responden 3 memiliki jumlah pendapatan Rp.28.108.950 dan reponden 4 jumlah pendapatannya Rp.16.057.500 sedangkan responden 5 memiliki jumlah pendapatan jauh dari responden yang lain. Dikarenakan luas lahan dan jumlah biaya dan pemakaian obat yang banyak dengan luasan lahannya 1,50 ha sehingga berpengaruh terhadap pendapatannya. Pendapatan Responden 5 yaitu Rp.13.742.750.

Rata-rata penerimaan keseluruhan petani responden dalam satu kali musim tanam (empat bulan) yaitu Rp.52.600.000. sedangkan rata-rata penerimaan petani responden berdasarkan luas lahan yaitu Rp.31.860.000 dan rata-rata biaya keseluruhan petani responden adalah Rp.20.750.580. rata-rata biaya berdasarkan luas lahan adalah Rp.13.018.318 dan ratarata pendapatan keseluruhan petani responden adalah Rp.31.849.420 sedangkan rata-rata pendapatan petani responden berdasarkan luas lahan yaitu Rp.18.704.342.

\section{Kelayakan Usahatani}

Kelayakan usahatani atau tingkat keuntungan dapat diketahui dengan menggunakan analisis Return Cost Ratio (R:C ratio). Analisis $\mathrm{R}: \mathrm{C}$ adalah perbandingan antara penerimaan dan biaya dari petani responden yang ada di Desa Kauditan 1.
Tabel 23. Hasil Analisis Return Cost Ratio

\begin{tabular}{cccc}
\hline Resp & $\begin{array}{c}\text { Total } \\
\text { Penerimaan } \\
(\mathrm{TR})\end{array}$ & $\begin{array}{c}\text { Total Biaya } \\
(\mathrm{TC})\end{array}$ & $\begin{array}{c}\text { Return/Cost } \\
(\mathrm{R} / \mathrm{C})\end{array}$ \\
\hline 1 & 90.000 .000 & 27.267 .050 & 3,30 \\
2 & 66.000 .000 & 27.395 .050 & 2,41 \\
3 & 48.000 .000 & 19.891 .050 & 2,41 \\
4 & 27.000 .000 & 10.942 .500 & 2,47 \\
5 & 32.000 .000 & 18.257 .250 & 1,75 \\
\hline Rata-rata & 52.600 .000 & 20.750 .580 & 2,47 \\
\hline
\end{tabular}

Hasil dari Tabel 23 menunjukan bahwa nilai $\mathrm{R} / \mathrm{C}$ dari responden 1 adalah 3,30, responden 2 yaitu 2,41, responden 3 adalah 2,41 , responden 4 adalah 2,47 sedangkan responden 5 yaitu 1,75 , dan nilai $\mathrm{R} / \mathrm{C}$ rata-rata adalah 2,47.

Usahatani dikatan layak atau menguntungkan apabila nilai $\mathrm{R} / \mathrm{C}$ lebih dari 1 , dan nilai dari usahatani padi sawah di Desa Kauditan 1 adalah 2,47 yang artinya adalah usahatani tersebut layak atau menguntungkan.

\section{KESIMPULAN DAN SARAN}

\section{Kesimpulan}

Hasil dari penelitian menunjukan bahwa pendapatan usahatani padi sawah di Desa Kauditan 1 bervariasi. Besarnya pendapatan yang diterima oleh petani tergantung pada luas panen dari lahan yang dimiliki dan kelayakan usahatani padi sawah di Desa Kauditan 1 adalah menguntungkan. Hal ini terlihat dari analisis R/C yang lebih dari 1 (satu) dan pendapatan rata-rata keseluruhan petani responden padi sawah didesa kauditan 1 Rp.31.849.420 dan pendapatan rata-rata berdasarkan luas lahan adalah Rp.18.780.342.

\section{Saran}

Untuk lebih meningkatkan pendapatan petani hendaknya melakukan perluasan area tanam dan perlu adanya pembinaan, sosialisasi budidaya padi sawah yang dilakukan secara berkelanjutan dalam rangka peningkatan wawasan dan pola pikir petani. 


\section{DAFTAR PUSTAKA}

Badan Pusat Statistik. 2016. Sensus pertanian. Http://MinutKab.bps.go.id/statictable,L uas panen -produksi -produktifitas kab, minut. 1 juni 2018.

Panggabean, Andreas. 2010. Posisi Pertanian dalam Teori Pembangunan Ekonomi Rostow dan Lewis. 